\title{
Dynamics of spatial patterns of microphytobenthic biomass: inferences from a geostatistical analysis of two comprehensive surveys in Marennes-Oléron Bay (France)
}

\author{
J.-M. Guarini ${ }^{1, *}$, G. F. Blanchard ${ }^{1}$, C. Bacher ${ }^{1}$, P. Gros ${ }^{2}$, P. Riera ${ }^{1}$, P. Richard ${ }^{1}$, \\ D. Gouleau ${ }^{1}$, R. Galois ${ }^{1}$, J. Prou ${ }^{1}$, P.-G. Sauriau ${ }^{1}$
}

'CNRS-IFREMER, Centre de Recherche en Ecologie Marine el Aquaculture de L'Houmeau, BP 5, F-17137 L'Houmeau, France ${ }^{2}$ IFREMER Centre de Brest, BP 70, F-29280 Plouzané, France

\begin{abstract}
Microphytobenthos plays an important role as primary producer in shallow embayments subject to a tidal regime. The present paper aims to characterize the spatial patterns of sedimentary chlorophyll a (chl a) biomass in 2 seasons in the wide intertidal mudflats of the Marennes-Oléron Bay (France); furthermore, it provides estimates of total microphytobenthic biomass. Accordingly, a systematic sampling scheme was performed in June 1995 and in January 1996. On average, biomass

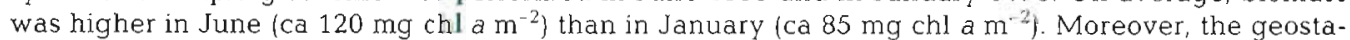
tistical analysis revealed that spatial similarities were propagated over larger distances in June $(6 \mathrm{~km})$ than in January $(2.2 \mathrm{~km})$. In order to accounli for this result, we suggost that seasonal dynamics of benthic microalgae biomass obeys a 'constant-density model' that describes the alternating spreading/shrinkage phenomenon around the few persistent patches of maximum biomass ( $\mathrm{ca} 300 \mathrm{mg} \mathrm{chl} \mathrm{a}$ $\left.\mathrm{m}^{-2}\right)$. Total biomass estimates were ca $13 \mathrm{t} \mathrm{chl} \mathrm{a}(\mathrm{SE}=0.26)$ in June and $10 \mathrm{t} \mathrm{chl} \mathrm{a}(\mathrm{SE}=0.28)$ in January. Calculating a raw approximation of the growth rate $\left(0.1 \mathrm{~d}^{-1}\right)$ of that biomass and considering that the total produced biomass is resuspended at flood tide, we found that microphytobenthos supplies about $2 \mu \mathrm{g} \mathrm{chl} \mathrm{a} \mathrm{l}^{-1}$, which corresponds to $30-90 \%$ of the chl a suspended in the water column, depending on the season. This suggests that microphytobenthos could be a major food source for secondary producers in both pelagic and benthic ecosystems of the Marennes-Oléron Bay.
\end{abstract}

KEY WORDS: Microphytobenthos Chlorophyll a Spatial distribution - Geostatistics - Intertidal mudflat

\section{INTRODUCTION}

The spatial distribution of sedimentary chlorophyll a (chl $a_{i}$ used as an index of microphytobenthic biomass) has been investigated in different types of environments and at different scales. Analysis of the spatial structures at microscale (within $1 \mathrm{~m}^{2}$ ) has shown that microphytobenthos patchiness may be due to sedimentary structures (Plante et al. 1985, 1986, Saburova et al. 1995) or benthic nutrient effluxes (Höpner \& Wonneberger 1985) and that it may be closely related to meiofauna patchiness because of trophic links

•E-mail: jmguari@ifremer.fr
(Decho \& Fleeger 1988, Blanchard 1990, Pinckney \& Sandulli 1990). Spatial structures at mesoscale, however (whole shallow bays and intertidal flats in estuaries), have not been analysed, even though mapping of chl a has been performed (Lukatelich \& McComb 1986, Sun et al. 1994]. These studies provide broad trends of the microphytobenthic biomass distribution: the highest biomass levels are usually associated with muddy sediments (rather than sandy ones), preferably in shallow subtidal areas or at high levels on intertidal flats (because of light availability) (Lukatelich \& McComb 1986, Delgado 1989, Burford et al. 1994, Brotas et al. 1995). Other works have addressed the effect of elevation and exposure (Colijn \& Dijkema 1981, Colijn \& de Jonge 1984, de Jonge \& Colijn 1994). 
These data are nevertheless insufficient to derive information for generating hypotheses pertaining to the functioning of the ecosystem. As outlined by Legendre \& Fortin (1989), spatial structure is an important element of ecological populations and communities, and studies on the spatial heterogeneity of ecological variables are useful to detect underlying structuring factors. In this paper, we wanted (1) to characterize the spatial heterogeneity (e.g. existence of patches and gradients) of the microphytobenthos biomass at the ecosystem scale, (2) to study the temporal stability or variability of the spatial structures, and (3) to relate our findings to ecological factors that may influence the spatial structure. Several techniques exist, including multivariate analysis, statistical tests of spatial heterogeneity, and descriptive methods (Legendre \& Fortin 1989). We have chosen the methods developed in the geostatistics frame for several reasons. These are basically univariate methods (though they can be extended to multivariate cases), which compare favorably to alternative techniques, to assess the spatial heterogeneities with a structure function (the variogram in the simplest case) which can be modeled in a wide range of situations (see below). The model allows the spatial autocorrelation to be represented as a function of the distance between points. One powerful aspect is that the variogram model can be used to estimate unknown values through kriging. During this stage, the values obtained from the sampling survey are combined and weighed to yield a map of the mean (and its variance) on a grid of points. The kriging equations also yield a total biomass estimate over the surveyed area. With respect to these goals, geostatistics has been successfully applied to different fields such as soil science and mining (Journel \& Huijbregts 1977, Oliver 1987), hydrology (Gohin \& Langlois 1991, Leenhardt et al. 1994), fisheries (Petitgas 1993, Maravelias \& Haralabous 1995) and different topics in ecology (Robertson 1987, Gros 1992, Rossi et al. 1992, Bacher \& Sauriau 1995).

The aim of this work was the identification of the spatial structure of sedimentary chl $a$ on the Marennes-Oléron Bay (France) intertidal flats, where microphytobenthos is the main primary producer (Cariou-Le Gall \& Blanchard 1995). Sediment samples were collected in 2 different seasons according to a systematic sampling scheme. These 2 sampling occasions coincide with the maximum (June) and minimum (January) chl a concentrations in the sediment (CariouLe Gall \& Blanchard 1995). Since the geostatistical procedure is based on assumptions on the spatial variability, we first established the weak stationarity of spatial increments of the sedimentary chl a biomass, therefore allowing us to summarize and model the biomass patterns by classical variogram functions. These models were then used to generate maps by kriging and to assess the accuracy of total chl a biomass estimates (at the scale of the whole bay). Variograms, kriged maps and global biomass estimations were carried out for June and January and the comparisons of the results provided information on the potential ecological factors responsible for the spatial patterns and their stability.

\section{MATERIAL AND METHODS}

Sampling strategy. Mesoscale sampling: Systematic sampling was carried out in June 1995 and in January 1996 in Marennes-Oléron Bay (Fig. 1). The total surface area of the bay is $1.81 \mathrm{~km}^{2}$ of which $110 \mathrm{~km}^{2}$ are intertidal. The dimensions of each element of the rectangular mesh of the sampling grid were $45^{\prime \prime}$ latitude $x$ $45^{\prime \prime}$ longitude $(1000 \times 1389 \mathrm{~m})$. The sediment was sampled at each node; as some nodes were just outside the limit of the intertidal area (either subtidal or terrestrial), they were shifted by $15^{\prime \prime}$ longitude $(333 \mathrm{~m})$ or latitude $(463 \mathrm{~m})$ within the sampling area. Furthermore, sampling sites were arranged crosswise at 3 locations, in order to investigate short-scale (withinmesh) variability (Fig. 1). Two of these 'criss-cross samplings' were on the eastern half of the bay (Brouage mudflat, B in Fig. 1) and a third one was on the western half (along Oléron Island, $O$ in Fig. 1). The within-cross sampling interval was $231 \mathrm{~m}$.

The nominal number of sampling sites was 141, but only 117 and 123 sites were effectively sampled in June 1995 and January 1996 respectively, because some locations were inaccessible. At each site, the sampling unit was the top $1 \mathrm{~cm}$ of $1 \mathrm{~m}^{2}$ of the sediment; the photosynthetically active biomass of benthic microalgae is indeed contained in this top layer (Blanchard \& Cariou-Le Gall 1994, MacIntyre \& Cullen 1995). The sites were sampled only during the emersion period during low tide, which required less than $10 \mathrm{~d}$ in each case. It was checked that the temporal variation of biomass during each period and within the low tide period was too low to interfere with the spatial variability (author's unpubl. data).

Subsampling: As it was impossible to collect the whole sample, a random subsampling was performed within the $1 \mathrm{~m}^{2}$ by sampling sediment cores. In order to choose the subsampling device yielding the best estimate of biomass within the sampling unit, the following comparison was carried out: 5 random replicates were performed independently with 4 core diameters $(3,6,8.0$ and $15.2 \mathrm{~cm})$. Let $\bar{y}_{3}$ and $V\left(\bar{y}_{j}\right)$ denote respectively the arithmetic mean of chl a biomass and its variance in the $j$ th subsample of 5 replicates $(j=1, \ldots, 4)$, and $\alpha$, the ratio of the sampling unit 


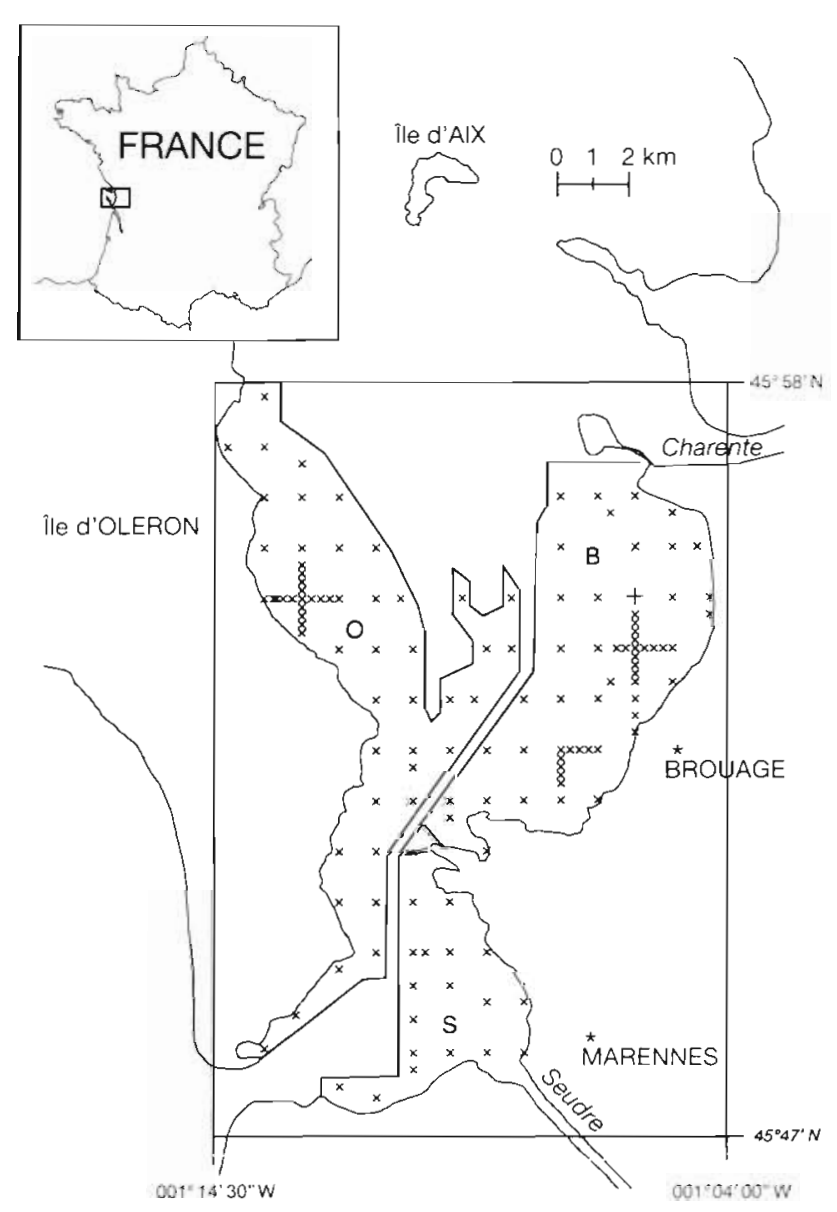

Fig. 1 The systematic sampling grid. $(x)$ Sampling stations where $177 \mathrm{~cm}^{2}$ triplicates of the surficial sediment were collected. At 3 locations, samples were laid crosswise, in order to characterize short-scale (i.e. within-mesh) spatial variability. O, B and S: Oléron, Brouage and Seudre mudflats respectively

area $\left(1 \mathrm{~m}^{2}\right)$ to the subsample area. Obviously, $\hat{b}_{j}=\alpha, \bar{y}_{j}$

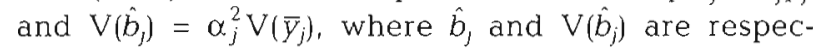
tively the estimator of the total amount $b$ of chl $a$ in $1 \mathrm{~m}^{2}$ of sediment and its variance. Results are shown in Fig. 2. A 1-way ANOVA led to the rejection ( $p<$ $0.05)$ of the null hypothesis $\left(b_{1}=\ldots=b_{4}=b\right)$; furthermore, a Newman-Keuls multiple range a posteriori test showed that the 'core effect' was attributable to the smallest subsampling area (i.e. $3 \mathrm{~cm}$ core diameter). According to the values shown in Fig. 2, the largest core size $(15.2 \mathrm{~cm}$ in diameter) was selected. Only 3 replicates were effectively sampled at each sampling site in order to restrict the number of chl $a$ analyses to ca 400 in each season.

Sedimentary chl a measurement. At each sampling location, the top $1 \mathrm{~cm}$ of the three $181 \mathrm{~cm}^{2}$ replicates was sampled and carefully mixed. A subsample was withdrawn from each of them, freeze-dried and kept in

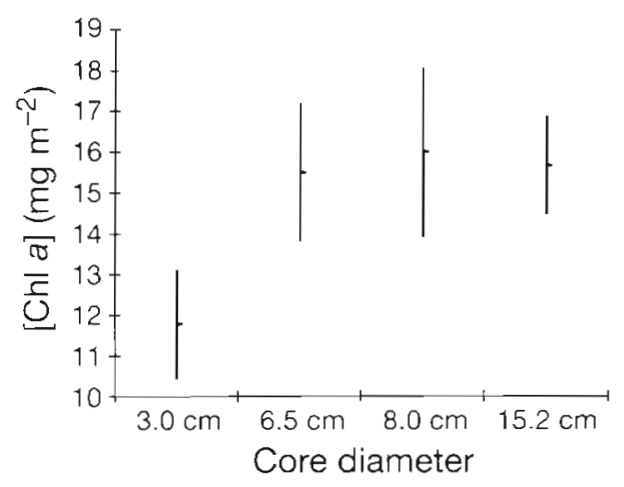

Fig. 2. Results of the pilot study aimed at choosing the subsampling unit (core diameter). Each biomass estimate (mean \pm SE) was obtained with 5 replicates; the whole set of $4 \times 5$ replicates was randomly collected in the same $1 \mathrm{~m}^{2}$ area

the dark at $-80^{\circ} \mathrm{C}$ until further processing. The chl a content of the dried sediment was extracted in $90 \%$ acetone during $18 \mathrm{~h}$ in the dark with agitation; chl a was then measured using the fluorometric method (Lorenzen 1966), and expressed as $\mathrm{mg} \mathrm{chl} a \mathrm{~m}^{-2}$.

Geostatistical analysis of spatial patterns. Basically, the geostatistical approach aims to characterize the patterns of similarities between sampling units across a continuum of spatial scales. Each sampling unit is considered as the outcome of a random function (RF), which is a function of space coordinates (Matheron 1971). Chi a sedimentary biomass is represented by a stochastic process $B(x)$, where $x$ denotes the location in the Marennes-Oléron Bay. Because of the dependency of $B$ on $x_{1}$ the RF $B(x)$ is said to be regionalized. Predicting the values of $B$ at some points in space from the known values at sampling points is possible if some model of the spatial structure can be derived from the data. The structural analysis is explained below, and the way the spatial structure model is used for the estimation of unknown values is developed in the following section. These steps are then applied to the data collected in January and June and the structures, maps and global estimations compared.

Structural analysis: Sampling the stochastic process provided the actual set of $n$ observations of $b\left(x_{1}\right)$, the $x_{i}$ 's corresponding to the spatial coordinates of the sampling grid nodes. As this sample is the only available realization of the $R F B(x)$, some assumptions are necessary to make statistical inference possible. The strongest hypothesis would be the stationarity of the RF [i.e. all the moments of the RF $B(x)$ are invariant under translation]. However, we shall put ourselves in a much less restricting framework, because (1) the expectation $E[B(x)]$ cannot realistically be assumed to be independent of $x_{1}$ and (2) we only require stationarity of the first 2 moments, mean $E$ and variance $V$, for linear estimations. In other words, we only 
need the weak stationarity of the first-order space differences of $B(x)$, i.e.

$$
\left\{\begin{array}{l}
\mathrm{E}[B(x+h)-B(x)]=0 \\
\mathrm{~V}[B(x+h)-B(x)]=2 \gamma(h)
\end{array}\right.
$$

This is the so-called 'intrinsic hypothesis' (Journel \& Huijbregts 1977), according to which the variance of the increments exists, is independent of $x$, and is a function $\gamma(h)$ of the distance $h$ between the 2 locations $x$ and $x+h$ only. $\gamma(h)$ is called the variogram and the RF $B(x)$ is said to be intrinsic (IRF). It is worth noting that $\gamma(h)$ is defined only when the expectation of the space increments is zero; $B(x)$ is then an IRF-0. In practice, we thus have to check whether the order $k$ of the IRF is 0 , or if there is a linear $(k=1)$ or a quadratic $(k=2)$ drift in the IRF at the scale of observation. This preliminary test is performed according to the procedure described below. When the data set $\left\{b\left(x_{1}\right)\right\}_{i=1, \ldots, n}$ is in favor of $k=0$, the experimental variogram is computed:

$$
\hat{\gamma}(h)=\frac{1}{2 n(h)} \sum_{l=1}^{n(h)}\left[b\left(x_{l}+h\right)-b\left(x_{1}\right)\right]^{2}
$$

where $n(h)$ is the number of pairs of observations $\left\{b\left(x_{j}\right)\right.$, $\left.b\left(x_{i}+h\right)\right\}$. The graph of $\hat{\gamma}(h)$ versus $h$ is a powerful tool for the analysis of the IRF $B(x)$ : it provides information (1) on the short-scale heterogeneity, (2) on the 'strength' of the spatial structure, and (3) on the distance beyond which spatial correlations between samples become negligible. Furthermore, the fit of $\hat{\gamma}(h)$ to an analytical model allows maps to be built by ordinary kriging, i.e. by linear combination of observed values $b\left(x_{1}\right)$

Local linear kriging and mapping: Let $x^{*}$ be any point (sampled or not) in the Marennes-Oléron Bay. In linear kriging, the estimate $b^{*}$ of the chl a biomass at $x^{*}$ is a weighted sum of $p$ neighbouring data points $b\left(x_{i}\right)$ :

$$
b^{*}=\sum_{i=1}^{\mathrm{p}} \lambda_{i} b\left(x_{i}\right), \text { with } \sum_{i=1}^{\mathrm{p}} \lambda_{i}=1
$$

where $\lambda_{i}$ is the unknown weight of the $i$ th observation. The equality constraint on the real coefficients $\lambda_{l}$ is a non-bias condition. These weights are calculated in such a way that the estimation variance is minimal. It may be shown that the variance $V$ of the estimator $b^{*}$ is:

$$
\mathrm{V}\left(b^{*}\right)=-\sum_{i} \sum_{j} \lambda_{i} \lambda_{j} \gamma\left(x_{i}-x_{j}\right)
$$

The unknown weights $\lambda_{i}$ and $\lambda_{j}$ (for the $i$ th and $j$ th observations, respectively) are identified by minimization of $\mathrm{V}\left(b^{*}\right)$ conditionally to a given model of variogram $\gamma(h)$. To resume, this makes the kriging estimator $b^{\cdot}$ optimal in the class of linear estimators (it is unbiased and minimizes the variance). Eq. (4) stresses the importance of the variogram model choice. Consequently, some criteria derived from cross-validation are used to assess the quality of the fit of $\hat{\gamma}(h)$ to a theoretical function $\gamma$. Let $b_{-i}^{*}$ denote the estimation at $x_{j}$ after removal of the $i$ th datum $b\left(x_{1}\right)$; we used the following criteria (Journel \& Huijbregts 1977):

$$
\begin{aligned}
& \rho=\frac{1}{n} \sum_{i=1}^{n} \frac{b\left(x_{i}\right)}{b_{-i}^{*}}, \quad \delta=\frac{1}{n} \sum_{i=1}^{n}\left[b\left(x_{i}\right)-b_{-i}^{*}\right], \\
& v=\frac{1}{n} \sum_{i=1}^{n} V\left[b\left(x_{i}\right)\right] / \sum_{i=1}^{n}\left[b\left(x_{i}\right)-b_{-i}^{*}\right]^{2}
\end{aligned}
$$

Clearly, $\rho$ and $v$ must be close to 1 whereas $\delta$ must be close to 0 . Although these criteria are not designed to perform statistical tests, the last two help to identify separately lack-of-fit causes when checking variogram models: (1) a $\delta$ value far from zero suggests a poorly estimated range; (2) conditionally to $\delta \approx 0$, a $v$ substantially lower than 1 (respectively greater) indicates that the sill is overestimated (respectively underestimated).

The variogram $\gamma$ has to be chosen in a well-defined class of functions ensuring the positiveness of $\mathrm{V}\left(b^{*}\right)$. For that reason, we used some classical models ('spherical', 'gaussian' and 'exponential'), fulfilling this condition.

Global estimation: In the absence of any spatial periodicity in the IRF $B(x)$, the systematic sampling scheme ensures the lack of bias of the arithmetic mean as an estimator of the average chl a biomass; obviously, the same result holds for the total biomass estimate. One point of great interest in the geostatistical approach is in using information from spatial patterns (expressed by the function $\gamma$ in the present case) to increase the accuracy of the estimates. Let $S$ denote a given area where no sampling occurred and $x_{1}$ the locations of sampling sites surrounding the area $S$. Further, let $\hat{B}$ be the estimator of the mean biomass $\mathrm{E}[B(x)]$ in $S_{i}$ the kriging variance of $\hat{B}$ is

$$
\mathrm{V}(\hat{B})=-\sum_{i} \sum_{j} \lambda_{i} \lambda_{j} \gamma_{i j}+2 \sum_{j} \lambda_{j} \bar{\gamma}_{L S}-\bar{\gamma}_{S S}
$$

where $\gamma_{i j}$ stands for $\gamma\left(x_{1}-x_{j}\right)$. A formal definition of the space integrals $\hat{\gamma}_{i s}$ and $\hat{\gamma}_{S S}$ can be found in Journel \& Huijbregts (1977). Let us only emphasize that $\hat{\gamma}_{i s}$ depends on the relative positions of the $x_{1}^{\prime}$ 's with respect to $S$-hence on the sampling scheme-and $\hat{\gamma}_{S S}$ on the shape of the area $S$ itself. In the following, a numerical approximation of Eq. (5) was performed to compute the standard error of the total chl a biomass estimate.

\section{RESULTS}

\section{Basic statistics}

The measured sedimentary chl a concentrations in the Marennes-Oléron Bay are given in Fig. 3 for both the summer and winter periods. In each case, the dis- 

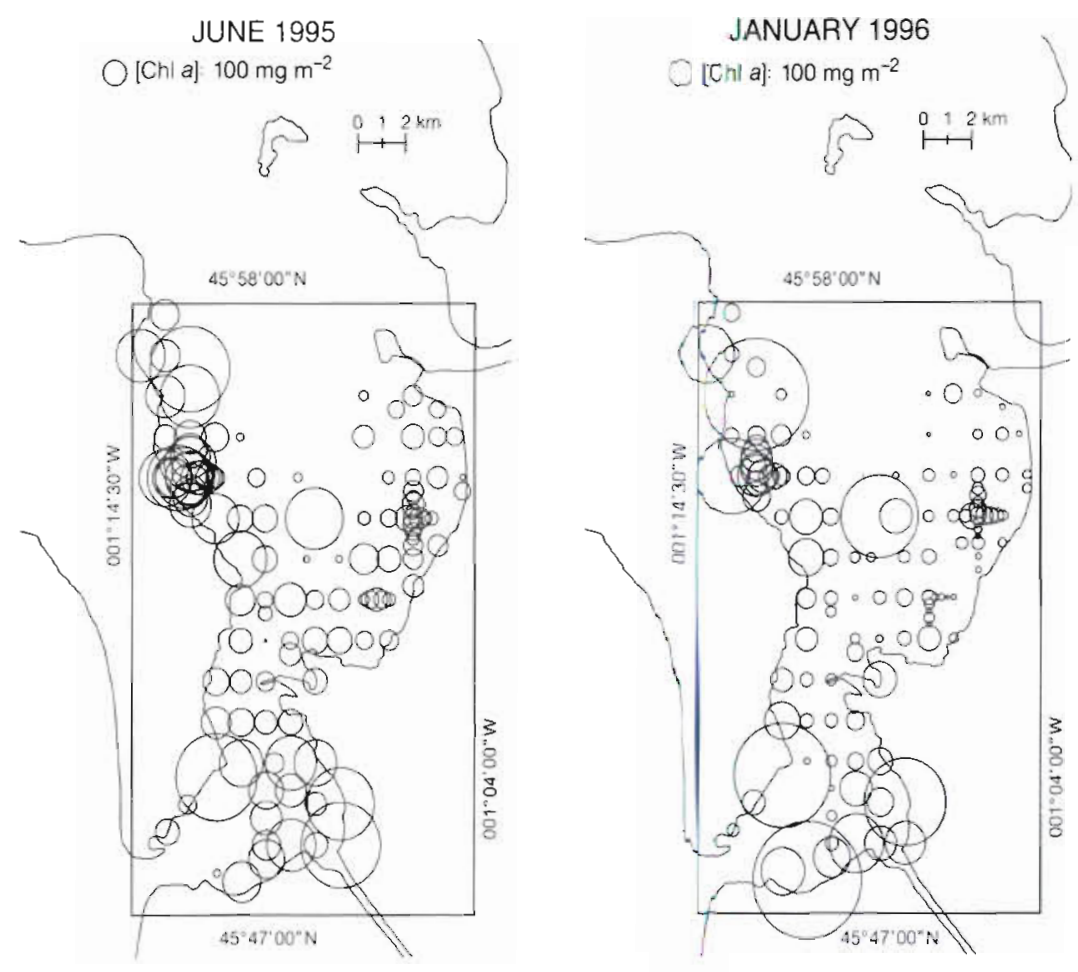

Fig. 3. Measured chl a biomass from samples collected in June 1995 and January 1996
Fig. 4 shows that datasets contain high influential values ( $>300 \mathrm{mg} \mathrm{chl} \mathrm{a}$ $\mathrm{m}^{-2}$ ): 3 for June and 6 for January. Their removal brings down mean estimates 15 and $18 \%$ decrease respectively), and above all variance estimates $(28$ and $70 \%$ decrease respectively).

\section{Structural analysis}

The first step was the identification of the order $k$ of the IRF $B(x): 3$ models were compared (IRF-0, -1, and -2 , corresponding respectively to no drift, linear drift and quadratic drift) by forming 83 groups of neighbouring data points, any 2 points within a group being at most $4 \mathrm{~km}$ apart. For each group, residual sums of squares (RSS) of the fits of the 3 models were computed and ranked in increasing order. The least values of both RSS and rank, after averaging over all groups, determine the choice of the tribution of pooled data is unimodal and skewed to the right, with a more pronounced skewness in January 1996 (Fig. 4). In June, values were within the range 13.3 to $347.2 \mathrm{mg} \mathrm{chl} \mathrm{a} \mathrm{m}^{-2}$ with an arithmetic mean of $118 \mathrm{mg}$ chl $\mathrm{a} \mathrm{m}^{-2}$, whereas in January the range was

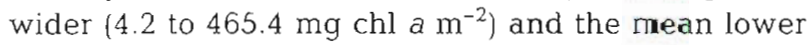
$\left(85.7 \mathrm{mg}\right.$ chl $\left.\mathrm{a} \mathrm{m}^{-2}\right)$. A classical Student pared $t$-test showed that the 2 average biomasses were significantly different ( $p<0.001$ ).

Table 1 also shows disaggregated results according to the different geographic sectors of the bay: the westward mudflat of Oléron. Island $\left(O, 45.5 \mathrm{~km}^{2}\right)$ and the continent-side mudflats, Brouage (B; $39.6 \mathrm{~km}^{2}$ ) and Seudre $\left(\mathrm{S} ; 20 \mathrm{~km}^{2}\right.$ ) (Fig. 1). In every case, the variance within sampling locations (due to microscale patchiness) is always much lower than the variance between locations (between samples). These results hold at the scale of the whole bay and for geographic sectors $O$, $\mathrm{B}$ and $\mathrm{S}$ as well. In June, the within-sample noise amounts to $15 \%$ of the total variance, but it is lower in January (ca 5\%). More generally, the spatial component of the variance (between geographic sectors, within-season) exceeds the temporal variability (between-season difference in average chl a concentration; see Table 1 and Fig. 3). In short, ch1 a biomass is on the whole higher in June than in January (Fig. 4), the striking feature being the high values observed in $O$ and $S$ in both seasons (Fig. 3).
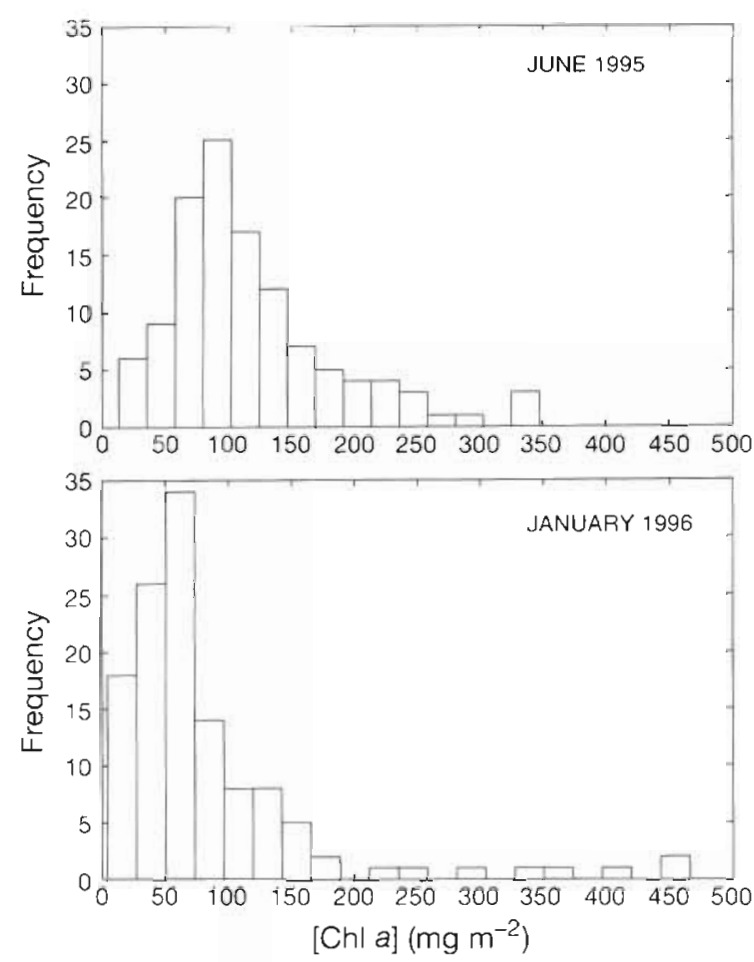

Fig. 4. Sample frequency distributions of chl a biomass in June 1995 and January 1996. The 2 histograms are one-side heavy tailed, especially in January where 6 extreme values

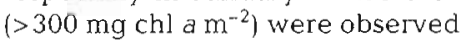


Table 1 Basic sample statistics computed for the whole bay, Oléron Island and Brouage and Seudre mudflats in the summer and winter periods

\begin{tabular}{|c|c|c|c|c|c|}
\hline & 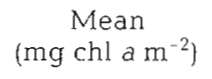 & $\begin{array}{c}\text { Within-sample } \\
\text { (between-subsample) variance }\end{array}$ & $\begin{array}{c}\text { Between- } \\
\text { sample variance }\end{array}$ & $\begin{array}{c}\text { Range } \\
\left(\mathrm{mg} \mathrm{chl} a \mathrm{~m}^{-2}\right)\end{array}$ & $\begin{array}{l}\text { Number of } \\
\text { of samples }\end{array}$ \\
\hline \multicolumn{6}{|l|}{ June } \\
\hline Whole bay & 118 & 583 & 4504 & $13.3-.347 .2$ & 117 \\
\hline Oléron & 146 & 866 & 5245 & $13.3-34.7 .2$ & 51 \\
\hline Brouage & 76 & 269 & 424 & $24.6-124.3$ & 48 \\
\hline Seudre & 148 & 639 & 5936 & $31.7-340.9$ & 18 \\
\hline \multicolumn{6}{|l|}{ January } \\
\hline Whole bay & 85 & 214 & 6746 & $4.2-465.5$ & 123 \\
\hline Oléron & 107 & 215 & 8524 & $4.2-448.2$ & 50 \\
\hline Brouage & 49 & 67 & 568 & $15.7-144.9$ & 55 \\
\hline Seudre & 138 & 674 & 1.3368 & $23.3-465.5$ & 18 \\
\hline
\end{tabular}

order $k$. The results in Table 2 show that the intrinsic hypothesis is appropriate for the statistical description of $B(x)$, which will be treated as an IRF-0 hereafter.

The second step was to compute experimental semivariogram $\gamma(h)$; this involved a discretization by step $\Delta h$ of the distance $h$ within the range 0.3 to $6.6 \mathrm{~km}$, with $\Delta h=600 \mathrm{~m}$. Let $D_{k}$ be the distance interval $\left[h_{k}, h_{k}+\Delta h\right]$ When grouping data pairs belonging to a given interval $D_{k}$ (i.e. all pairs $\left\{b\left(x_{i}\right), b\left(x_{i}\right)+h\right\}$ where $h \in D_{k}$ ) the Oléron Island mudflat $(O)$ and the continent-side mudflats (B and S) were treated separately, taking the discontinuity due to the axial subtidal channel into account (see Fig. 1). The 2 subsets were then pooled together for the computation of $\hat{\gamma}(h)$ over the entire sampling grid.

Eq. (2) shows that $\hat{\gamma}(h)$ is a variance estimator; such a statistic is non-robust, i.e. it is highly sensitive to extreme values (see for example Hampel et al. 1986). It may be suspected that the 6 high biomass values

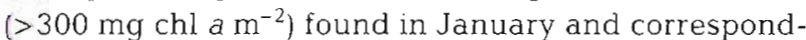
ing to the tail of the distribution (Fig. 4) may alter the true spatial structure revealed by the variogram. Two variograms were therefore computed: one with and one without the 6 highest observations. A model was fitted to each experimental variogram and tested with

Table 2. Identification of the order, $k$, of the IRF $B(x)$. Three models ( $k=0,1$ and 2 ) are compared using 2 criteria (RSS residual sums of squares; and rank, in increasing order, of the RSS of the 3 model fits) averaged on several groups of data points. Results shown here allow us to conclude that $B(x)$ should be modeled by an IRF-0 for spatial scales of ca $20 \mathrm{~km}^{2}$

\begin{tabular}{|c|c|c|c|c|}
\hline \multirow[t]{2}{*}{$k$} & \multicolumn{2}{|c|}{ June } & \multicolumn{2}{|c|}{ January } \\
\hline & $\begin{array}{c}\text { Average } \\
\text { RSS }\end{array}$ & $\begin{array}{c}\text { Average } \\
\text { rank }\end{array}$ & $\begin{array}{c}\text { Average } \\
\text { RSS }\end{array}$ & $\begin{array}{c}\text { Average } \\
\text { rank }\end{array}$ \\
\hline 0 & 4160 & 1.72 & 1351 & 1.56 \\
\hline 1 & 4607 & 1.88 & 1711 & 1.95 \\
\hline 2 & 10130 & 2.40 & 2636 & 2.49 \\
\hline
\end{tabular}

the cross-validation procedure - the ultimate way to decide which model is more appropriate.

Results are shown in Fig 5: the spatial structures were described by 2 distinct variogram models. For June, $\hat{\gamma}(h)$ was fitted to an exponential semi-variogram $\gamma(h)$ :

$$
\gamma(h)=c+w[1-\exp (-h / a)]
$$

where $c$ and $w$ denote nugget and sill respectively; $a$ is a parameter from which the practical range, $3 a$ (Journel \& Huijbregts 1977 ) is deduced, which is the distance where $\gamma(h)$ equals $95 \%$ of the asymptotic value $w+c$. For January, $\hat{\gamma}(h)$ computed for the bulk of the data was fitted to a spherical model:

$$
\begin{cases}\gamma(h)=c+w\left(1.5 h / a-0.5 h^{3} / a^{3}\right) & \text { if } 0<h<a \\ \gamma(h)=c+w & \text { if } h \geq a\end{cases}
$$

In this case, a denotes the range of the variogram. Parameter estimates for both models are presented in Table 3. All 3 parameters exhibit larger values in June: short-scale variability (1uggget) and between sampling sites chl a variability (sill) are about 3 times larger than the corresponding January estimates. In addition, spatial similarities spread over greater distances in June (practical range of $6 \mathrm{~km}$ in June vs $2.2 \mathrm{~km}$ in January).

Criteria designed to assess the quality of the fit $(\rho, v$ and $\delta_{;}$see Table 3 ) are close to their target values $(1,1$ and 0 respectively). With respect to these criteria, it is worth emphasizing the damaging effect of the 6 extreme chl a values in January (Table 3); even though the sill estimate is, as expected, strongly inflated, the other 'structure summarizers' (nugget and range) remain unaffected. The variogram fitted to the reduced January dataset was thus used for the interpolation over the whole sampling grid. The 6 values removed from the variogram functions were not considered as outliers in the following analysis, and were kept in the kriging equations (see below). 

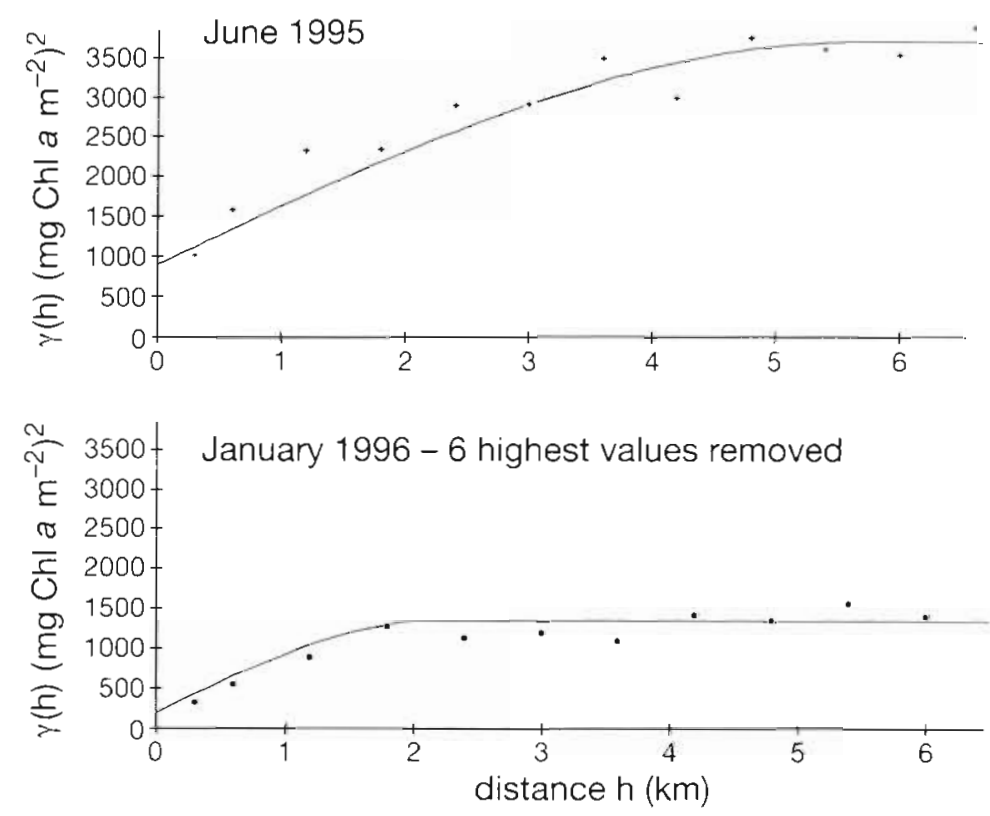

Fig. 5. Experimental semı-variograms (points) and theoretical models (continuous lines) fitted to the complete June dataset (exponential model), and to the January dataset aftcr removal of $6 \mathrm{chl}$ a values which were $>300 \mathrm{mg}$

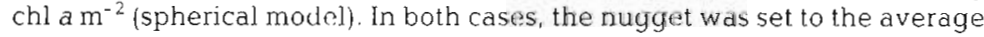
within-subsample vanance estimate

winter is mainly attributable to a betweenpatch decrease in biomass: the high concentration areas shrink between June and January, thus generating steeper chl a gradients accounting for the smaller range of the winter variogram when compared with the summer one (cf. Fig. 5, Table 3).

In addition, patchiness mainly occurred on the Oléron Island and Seudre mudflats, whereas biomass turned out to be relatively homogeneous on the Brouage mudflat with a lower level of biomass in both seasons. The latter was actually due to the absence of patches like those in the other sectors of Marennes-Oléron Bay.

The standard error of biomass estimates is shown in Fig. 7 As usual, the highest accuracy is achieved in the neighbourhood of sampling sites. More generally, the standard error is on the whole 2 orders of magnitude below the estimated values; its homogeneous distribution suggests further that the sampling scheme does not suffer from local deficiencies.

\section{Total biomass estimates}

Finally, we checked for anisotropy in both seasons by constructing separate variograms in the north-south and east-west directions, despite the relatively low sample density in the latter. The results (not shown) are consistent with the simple models retained here, which assume isotropic spatial patterns at the observational scale.

\section{Kriging}

Interpolation of sedimentary chl a biomass was performed according to Eq. (3), and the resulting maps are presented in Fig. 6. As a whole, these maps clearly show that the biomass level was higher in June than in January; furthermore, the main patches exhibit apparent stability both in their location and in chl a concentration level (>200 $\mathrm{mg} \mathrm{chl} \mathrm{a} \mathrm{m}^{-2}$ ) at their centers. As a consequence, the lower average quantity of chl a observed in
I'he totai quantity of chi $\alpha$ in ine iop centimeter of the intertidal mudflats amounted to 12.9 and $9.9 \mathrm{t}$ in June and January respectively (Table 4). We can calculate, with the notations previously used, the total chl a biomass as follows:

$$
\text { Total chl } a=\int_{A} B(x) \mathrm{d} x
$$

where $A$ is the mudflat area. Systematic sampling of the $110 \mathrm{~km}^{2}$ area provides accurate estimates: their coefficient of variation is at most $3 \%$. Comparison with the results that would be obtained without taking spatial structure into account, i.e. by computing standard errors from classical formula instead of Eq. (5), shows that the kriging approach increases the estimation accuracy by a factor of 2 in both seasons.

Table 3. Variogram models parameter estimates for the complete June dataset and for the January dataset with and without the 6 extreme chl a values. The last 3 columns exhibit 'gauging criteria' values (see 'Mciterial and methods'), which attest to the poor results from the fit to all January data points

\begin{tabular}{|llcccccc|}
\hline & $\begin{array}{l}\text { Variogram } \\
\text { model }\end{array}$ & $\begin{array}{c}\text { Nugget } \\
\left(\mathrm{mg} \mathrm{chl} \mathrm{m} \mathrm{m}^{-2}\right)^{2}\end{array}$ & Sill & $\begin{array}{c}\text { Range } \\
(\mathrm{km})\end{array}$ & $\rho$ & $\begin{array}{c}\delta \\
\left(\mathrm{mg} \mathrm{chl} \mathrm{m} \mathrm{m}^{-2}\right)\end{array}$ \\
\hline June & Exponential & 580 & 3420 & 6.0 & 0.82 & 1.10 & 0.71 \\
January (bulk of data) & Spherical & 210 & 1150 & 2.2 & 1.15 & 0.88 & 0.42 \\
January (all data) & Gaussian & 210 & 4100 & 1.9 & 1.50 & 0.76 & 0.92 \\
\hline
\end{tabular}



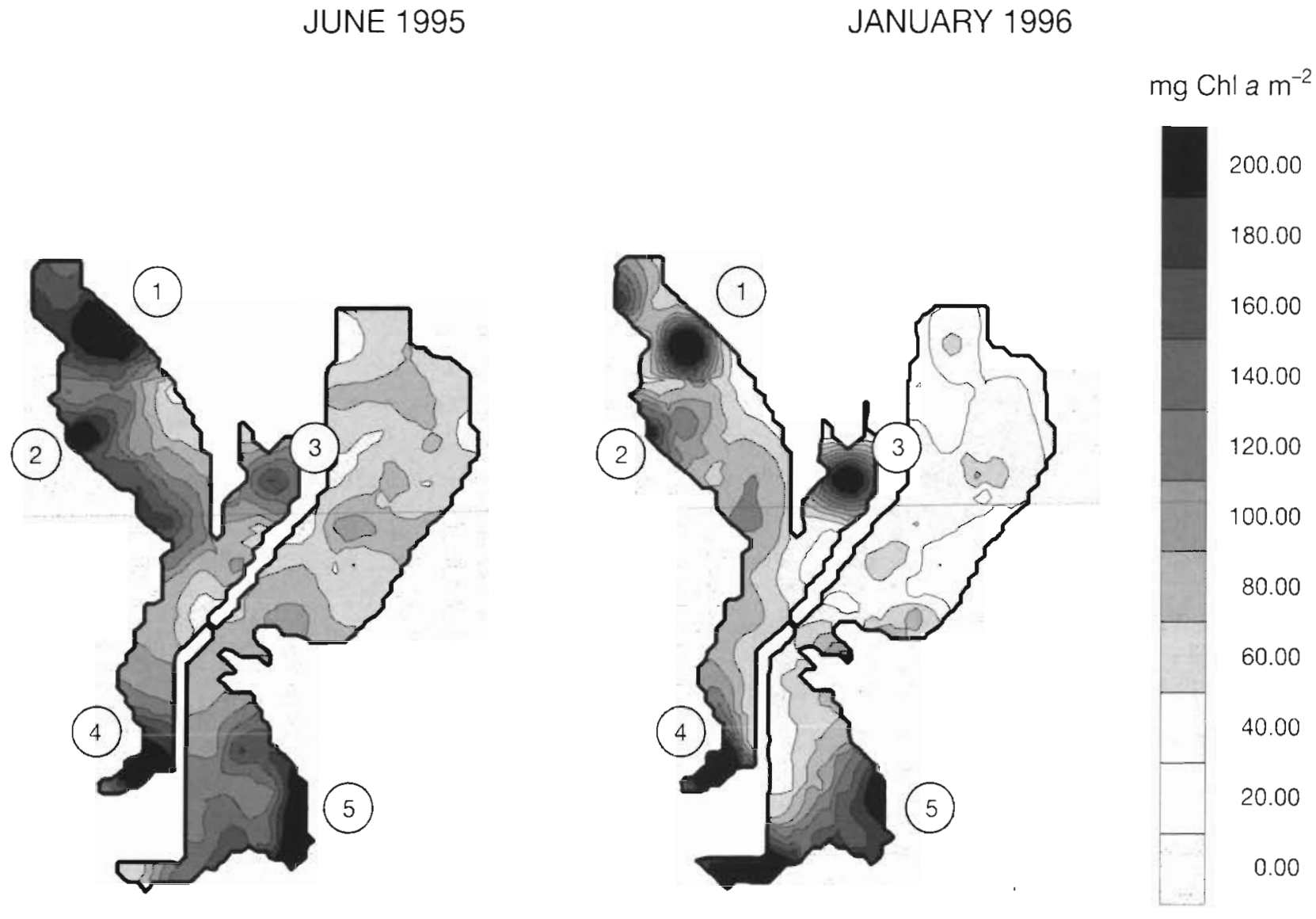

Fig. 6. Kriged maps of the top centimeter sedimentary chl a biomass in June 1995 and January 1996. Computations were performed over a $250 \times 250 \mathrm{~m}$ regular interpolating grid covering the sampled area (intertidal zone of $110 \mathrm{~km}^{2}$ ). Numbers 1 to 5 identify 'persistent patches' (see 'Discussion')

\section{DISCUSSION}

\section{Seasonal dynamics of microphytobenthos spatial structures in Marennes-Oléron Bay}

The geostatistical analysis reveals that the distribution of sedimentary chl a did not exhibit the same level of spatial dependence-the structure-in June and January: the stochastic processes which they-the structures-refer to and their constitutive parameters were different (Fig. 5, Table 3). Nevertheless, the kriged maps display common characteristics which suggest that the spatial patterns in June and January might have been generated by similar structuring processes

In summer, sedimentary chl a was characterized by an aggregated distribution in the Oléron Island and Seudre mudflats, but the distribution was much less aggregated in the Brouage mudflat (Fig. 6). The same general pattern was observed 6 mo later, in January, with a lower average biomass (Table 4), according to the seasonal cycle of biomass (Cariou-Le Gall \& Blanchard 1995). Therefore, this obvious contrast in the degree of patchiness of microphytobenthic biomass as a function of geographic sector (Brouage vs the rest of the bay) is one of the prominent features in MarennesOlèron Bay.

In addition, the patches of high biomass observed both in summer and in winter were at the same locations in the bay [Fig. 6, patches no. (kernels) 1 to 5]; they appear to be persistent patches. There was also a

Table 4. Global estimates of sedimentary chl a biomass over the whole intertidal area $\left(110 \mathrm{~km}^{2}\right)$. Average chl a concentration, with estimated standard error computed according to

Eq. (5), and total chl a in Marennes-Oléron Bay are given

\begin{tabular}{|ccc|} 
& $\begin{array}{cc}\text { Mean }(\mathrm{SE}) \\
\left(\mathrm{mg} \mathrm{chl} \mathrm{m} \mathrm{m}^{-2}\right)\end{array}$ & $\begin{array}{c}\text { Total }(\mathrm{SE}) \\
(\mathrm{t} \mathrm{chl} \mathrm{a})\end{array}$ \\
\hline June & $117.1(2.36)$ & $12.87(0.26)$ \\
January & $89.9(2.59)$ & $9.88(0.28)$ \\
\hline
\end{tabular}




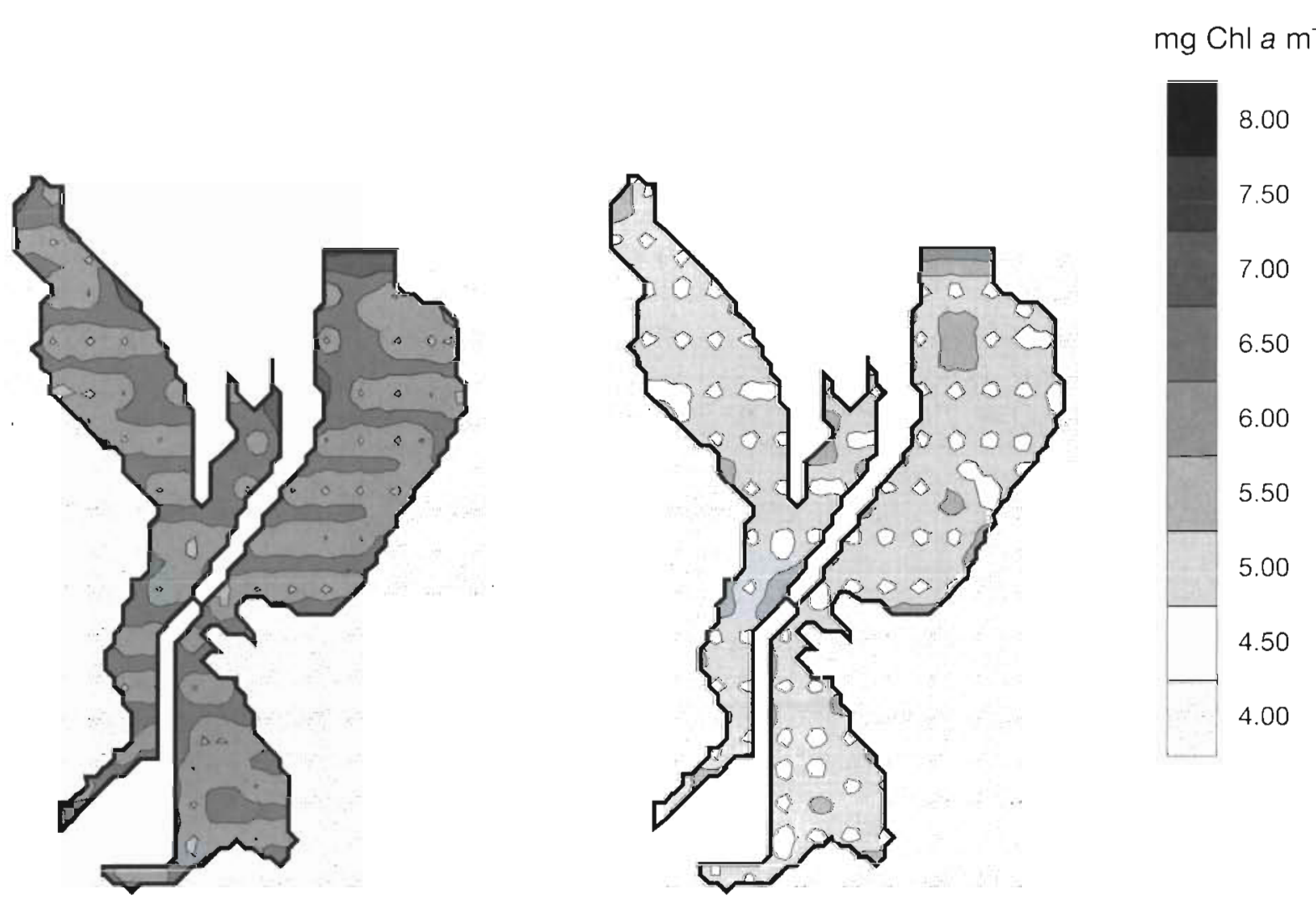

Fig. 7. Maps of kriging error This figure emphasizes the advantage of a systematic scheme over a random one: the betweensample distances are maximized, thus ensuring a regular distribution of the sampling effort. As a consequence, the result shown here is a fairly homogeneous distribution of uncertainty over the investigation area

decrease in the size of these patches from summer to winter, as confirmed by the decrease of the variogram range (from 6 down to $2.2 \mathrm{~km}$; Table 3 ). Thus, the large and partially overlapping summer patches became smaller and well separated in winter (Fig. 6). If we assume that such an observed pattern is representative of the summer and winter conditions, it is likely that the persistent patches contract from summer to winter and expand from winter to summer. The difference in the mean biomass level in the bay would thus be due to this contraction-expansion process. So, we propose that the seasonal variability of microphytobenthic biomass distribution follows a 'constant-density model', rather than a 'proportional-density model'. According to the former, a global increase (respective decrease for the latter) in chl a biomass raises up (respectively reduces) the size of the patches, without modifying the level of chl a concentration at their centers. Obviously, the reverse scheme defines the proportional-density model (Iles \& Sinclair 1982, Gauthiez 1997, Petitgas in press). From an ecological point of view, this implies some limitations of the local chl a concentration in the sediment [upper bound of ca 200 to $300 \mathrm{mg} \mathrm{chl} \mathrm{a} \mathrm{m} \mathrm{m}^{-2}$ in the present study, values which are within the range of the highest population densities reported by Admiraal et al. (1982)], which are compensated by spreading processes over surrounding areas. This raises the question of the processes structuring the spatial patterns.

\section{Structuring processes}

Microphytobenthos biomass distribution is the result of interacting processes; the most important process, primary production, accounts directly for biomass accumulation in the surficial sediment during the emersion periods. However, intertidal primary productivity of microphytobenthos is a non-stationary process strongly influenced by the duration of low tide and hence inversely related to the bathymetric gradient (Guarini et al 1997); this factor cannot account for the 
observed spatial distribution in the 2 seasons: there was no general trend of accumulation of biomass at the highest levels of the flats, even though this was the case in the central part of the Oléron Island side of the bay (Fig. 6). There was instead accumulation around the patches, which were not necessarily located at the highest bathymetric levels. As a matter of fact, every instantaneous sample of sedimentary chl a results from a balance between source (e.g. production, import) and $\operatorname{sink}$ (e.g. resuspension, grazing) dynamic processes, whose control-either by physical or biogeochemical factors - as well as effect vary from one location to the other within the bay. The available knowledge does not allow us to identify a dominant process, if any. However, some guesses may be put forward, according to environmental characteristics of each kernel: for instance, kernel 1 was related to the presence of mussel cultures where biodeposition was likely to stimulate nutrient cycling, kernel 2 corresponded to a muddier area generally characterized by higher levels of biomass, kernel 3 was associated with a site of oyster production which also generated biodeposition, kernel 4 was located at the mouth of the River Seudre and kernel 5 was near the effluent of an oyster pond area. Kernels 4 and 5 might have taken advantage of local nutrient inputs. By comparison with these sheltered areas, the relatively homogeneous Brouage mudflat is exposed to the predominant northwesterly winds; it is therefore likely that wind-induced waves could contribute to disperse benthic microalgae, thus not allowing an aggregated distribution.

\section{Comparison with other areas}

There have been very few studies providing maps of sedimentary chl a (Lukatelich \& McComb 1986, Delgado 1989, Burford et al. 1994); none of them have dealt with the analysis of spatial structures at the scale of a whole bay and only 2 have performed a winter versus summer comparison (Lukatelich \& McComb 1986, Delgado 1989). This emphasizes that the topic has been under-investigated so far, and any generalization is thus highly speculative. For those aspects of the spatial distribution which nevertheless may be compared, it turns out that the proposed description of seasonal dynamics of microalgae biomass distribution by a constant-density model has never been reported previously.

Concerning the more general typological aspect of the spatial distribution of microphytobenthos biomass, our findings are in opposition to previous observations which have established that microalgal biomass exhibits greater values on the highest levels of mudflats (Brotas et al. 1995). On the other hand, concerning the relationship between biomass and sediment type, our results are not necessarily opposite to what is usually acknowledged: the muddier the sediment, the greater the biomass (Lukatelich \& McComb 1986, Delgado 1989, Burford et al. 1994, Brotas et al. 1995). Indeed. although the biomass was higher on the Oleron Island side where the sediment is composed of sandy mud than in Brouage sector where the mud is very fine, it was mainly due to the presence of the superimposed patches, the presence of which was discussed previously.

Finally, in order to focus attention on the importance of microphytobenthos in the functioning of the ecosystem, it is worth attempting a rough assessment of microphytobenthos contribution to microalgal biomass suspended in the water column. It has been shown in Marennes-Oléron Bay (author's unpubl. data) that the net in situ growth rate of microphytobenthos in spring was about $0.1 \mathrm{~d}^{-1}$ in the top $1 \mathrm{~cm}$, and that almost all the daily produced biomass during emersion was resuspended during immersion (thus $10 \%$ of the biomass in the top $1 \mathrm{~cm}$ of the sediment). According to these conditions, microphytobenthos would supply about $2 \mu \mathrm{g}$ chl a $\mathrm{l}^{-1}$, which represents between 30 and $90 \%$ of the total chl a suspended in the water column, depending on the season. This suggests the high significance of microphytobenthos as a food source for secondary producers in the MarennesOléron Bay.

Acknowledgements. This study was supported by the Région Poitou-Charentes and by the European Community (MAST 3 CT95-0022 INTRMUD Project), associated with the Centre National de la Recherche Scientifique (CNRS) and the Institut Français de Recherche et d'Exploitation de la Mer (IFREMER). The authors are very grateful to Dr François Gauthiez (Ministère des Pèches Maritimes et des Cultures Marines) for his valuable contribution in all the steps of this work. The authors thank Martine Breret, Françoise Mornet and Dr Olivier Le Pape for performing the chl a measurements. We express also our gratitude to Pierre Petitgas (ORSTOM), Francis Gohin (IFREMER) and Jean-Jacques Lechauve (ORSTOM), who provided the software EVA and MAGIK and constant assistance with the statistical interpretations.

\section{LITERATURE CITED}

Admiraal W, Peletier $\mathrm{H}$, Zomer $\mathrm{H}$ (1982) Observations and experimentations on the population dynamics of epipelic diatoms from an estuarine mudflat. Estuar Coast Shelf Sci $14: 471-487$

Bacher C, Sauriau PG (1995) Structure spatiale et cartographie des peuplements benthiques du bassin de MarennesOléron: première approche par la méthode du krigeage. ICES Mar Sci Symp 199:231-246

Blanchard GF (1990) Overlapping microscale dispersion patterns of meiofauna and microphytobenthos. Mar Ecol Prog Ser 68:101-111

Blanchard GF, Cariou-Le Gall V (1994) Photosynthetic char- 
acteristics of microphytobenthos in Marennes-Oléron Bay, France: preliminary results. J Exp Mar Biol Ecol 182:1-14

Brotas V, Cabrita T, Portugal A, Serôdio J, Catarino F (1995) Spatio-temporal distribution of the microphytobenthic biomass in intertidal flats of the Tagus Estuary (Portugal) Hydrobiologia 300/301:93-104

Burford MA, Long BG, Rothlisberg PC (1994) Sedimentary pigments and organic carbon in relation to microalgal and benthic faunal abundance in the Gulf of Carpentaria. Mar Ecol Prog Ser 103:111-117

Cariou-Le Gall V, Blanchard G (1995) Monthly HPLC measurements of pigment concentration from an intertidal muddy sediment of Marennes-Oléron Bay, France. Max Ecol Prog Ser 121:171-179

Colijn F, Dijkema KS (1981) Species composition of benthic diatoms and distribution of chlorophyll $a$ on an intertidal flat in the Dutch Wadden Sea. Mar Ecol Prog Ser 4:9-21

Colijn $F$, de Jonge VN (1984) Primary production of microphytobenthos in the Ems-Dollard estuary. Mar Ecol Prog Ser 14:185-196

Decho AW, Fleeger JW (1988) Microscale dispersion of meiobenthic copepods in response to food-resource patchiness. J Exp Mar Biol Ecol 118:229-243

de Jonge VN, Colijn F (1994) Dynamics of microphytobenthos biomass in the Ems estuary. Mar Ecol Prog Ser 104: $185-196$

Delgado M (1989) Abundance and distribution of microphytobenthos in the Bays of Ebro Delta (Spain). Estuar Coast Shelf Sci 29:183-194

Gauthiez F (1997) Structuration spatiale des populations de poissons marins démersaux. Caractérisation, conséquences biométriques et halieutiques. PhD thesis, Lyon I University

Gohin F, Langlois G (1991) Atlas mensuel des températures moyennes dans le golfe de Gascogne. Oceanol Acta 14 $181-187$

Gros P (1992) Prévision à moyen terme des fluctuations des ressources halieutiques: modèles tautologiques ou autorégénérants? Ann Inst Océanogr 68(1-2):211-225

Guarini JM, Blanchard GF, Gros P, Harrison SJ (1997) Modelling the mud surface temperature on intertidal flats to investigate the spatio-temporal dynamics of the benthic microalgal photosynthetic capacity. Mar Ecol Prog Ser 153: $25-36$

Hampel FR, Ronchetti EM, Rousseeuw PJ, Stahel WA (1986) Robust statistics. The approach based on influence functions. John Wiley \& Sons, New York

Höpner T, Wonneberger K (1985) Examination of the connection between the patchiness of benthic nutrient efflux and epiphytobenthos patchiness on intertidal flats. Neth J Sea Res 19:277-285

Iles TD, Sinclair M (1982) Atlantic herring: stock discreteness and abundance. Science 215:627-633

Journel AG. Huijbregts CJ (1977) Mining geostatistics. Acad-

Editorial responsibility: Otto Kinne (Editor),

Oldendorf/Luhe, Germany emic Press, London

Leenhardt D. Voltz M, Bornand M, Webster R (1994) Evaluating soil maps for prediction of soil water properties. Eur J Soil Sci 45:293-301

Legendre P, Fortin MJ (1989) Spatial pattern and ecological analysis. Vegetatio 80:107-138

Lorenzen CJ (1966) A method for the continuous measurement of in vivo chlorophyll concentration. Deep Sea Res 13:223-227

Lukatelich RJ, McComb AJ (1986) Distribution and abundance of benthic microalgae in a shallow southwestern Australian estuarine system. Mar Ecol Prog Ser 27:287-297

MacIntyre HL, Cullen JJ (1995) Fine-scale vertical resolution of chlorophyll and photosynthetic parameters in shallowwater benthos. Mar Ecol Prog Ser 122:227-237

Maravelias CD, Haralabous J (1995) Spatial distribution of herring in the Orkney/Shetland area (Northern North Sea): a geostatistical analysis. Neth J Sea Res 34:319-329

Matheron G (1971) The theory of regionalized variables, and its applications. Cah Cent Morphol Math Fontainebleau 5:1-211

Oliver MA (1987) Geostatistics and its application to soil science. Soil Use Manage 3:8-20

Petitgas P (1993) Use of a disjunctive kriging to model areas of high pelagic fish density in acoustic fisheries surveys. Aquat Living Resour 6:201-209

Petitgas P (in press) Biomass-dependent dynamics of fish spatial distributions characterized by geostatistical aggregation curves. ICES J Mar Sci

Pinckney J, Sandulli R (1990) Spatial autocorrelation analysis of meiofaunal and microalgal populations on an intertidal sandflat: scale linkage between consumers and resources. Estuar Coast Shelf Sci 30:341-353

plante R, Plante-Cuny MR, Rey IP (1986) Photosynthetic pigments of sandy sediments on the North Mediterranean coast: their spatial distribution and its effect on sampling strategies. Mar Ecol Prog Ser 34:133-141

Plante R, Rey JP, Plante-Cuny MR (1985) Analyse spectrale, pigments chlorophylliens et rythmes sédimentaires. Un essai d'application. J Rech Oceanogr 10:100-101

Robertson GP (1987) Geostatistics in ecology: interpolating with known variance. Ecology 68:744-748

Rossi RE, Mulla DJ, Journel AD, Franz EH (1992) Geostatistical tools for modeling and interpreting ecological spatial dependence. Ecol Monogr 62:277-314

Saburova MA, Polikarpov IG, Burkovsky IV (1995) Spatial structure of an intertidal sandflat microphytobenthic community as related to different spatial scales. Mar Ecol Prog Ser 129:229-239

Sun MY, Aller RC, Lee C (1994) Spatial and temporal distributions of sedimentary chloropigments as indicators of benthic processes in Long Island Sound. J Mar Res 52: $149-176$

Submitted: September 19, 1997; Accepted: January 13, 1998 Proofs received from author(s): April 3, 1998 